\title{
Anti-inflammatory effects and GABA production of old antler and Auricularia auricula-judae extract fermented by Lactobacillus plantarum
}

\author{
Kwon soon young ${ }^{1}$, Whang $\mathrm{ki}^{1}$, Lee sam $\mathrm{pin}^{1,2 *}$ \\ ${ }^{1}$ Department of Food Science and Technology, Keimyung University, Daegu 42601, Korea \\ ${ }^{2}$ The Center for Traditional Microorganisim Resource (TMR), Keimyung University, Daegu 42601, Korea
}

\section{녹각 및 목이버섯의 젖산발효를 통한 GABA 생산 및 항염증활성 효과}

\author{
권순영 ${ }^{1} \cdot$ 황기 $^{1} \cdot$ 이삼빈 ${ }^{1,2 *}$ \\ ${ }^{1}$ 계명대학교 식품가공학과, ${ }^{2}$ 계명대학교 전통미생물자원계발 및 산업화연구센터
}

\begin{abstract}
The optimization of lactic acid fermentation was conducted to produce an old antler fortified with functional ingredients. For the over-production of gamma aminobutyric acid (GABA), the extract of old antlers (OA) was fermented by Lactobacillus plantarum EJ2015 with $0.5 \%$ YE, $1.5 \%$ glucose, and $3.5 \%$ MSG at $30^{\circ} \mathrm{C}$ for 7 days. The lactic acid fermented $\mathrm{OA}$ showed high viable cell counts of $2.0 \times 10^{8} \mathrm{CFU} / \mathrm{mL}$, $\mathrm{pH} 6.56$ and $0.77 \%$ acidity after 7 days. Addition of Auricularia auricula-judae (AAJ) enhanced the cell growth of $L$. plantarum EJ2014, resulting in higher viable cell counts of $2.0 \times 10^{9} \mathrm{CFU} / \mathrm{mL}$ and acid production after fermentation for 1 day. In particular, acidity was greatly decreased after fermentation for 3 days and $1.4 \%$ GABA was produced by converting efficiently mono sodium glutamate as a substrate. Fermented OA/AAJ mixture indicated the reduced cytotoxicity compared with that of unfermented OA. The fermented OA/AAJ mixture indicated anti-inflammatory effect with less production of NO in microphage cells. The production of NO dropped to $17.75 \mu \mathrm{M}$ at $4 \mathrm{mg} / \mathrm{mL}$, and to $5.58 \mu \mathrm{M}$ at $6 \mathrm{mg} / \mathrm{mL}$ old antler after fermentation. Thus, lactic acid fermented OA with AAJ could fortify GABA, probiotics and dietary fiber.
\end{abstract}

Key words : GABA, Lactobacillus plantarum, nitric oxide, cytotoxicity, antioxidant activity

\section{서 론}

전통발효식품에서 분리된 락토바실러스 플랜타룸 (Lactobacillus plantarum) 균주는 포도당으로부터 젖산을 주로 생산하여 발효제품의 신맛과 저장성을 향상시켜주며, 기능성물질인 y-amino butyric acid(GABA)를 고농도로 생 산하는 특징을 가지고 있다(1,2). 자연 상태에서의 식품 중 $\mathrm{GABA}$ 함유량으로는 약리작용을 발휘하기에 부족하여, 자

*Corresponding author. E-mail : splee@kmu.ac.kr

Phone : 82-53-580-5554, Fax : 82-53-580-5729

Received 23 January 2017; Revised 4 April 2017; Accepted 10 April 2017.

Copyright (c) The Korean Society of Food Preservation. All rights reserved.
연적인 섭취로 $\mathrm{GABA}$ 의 생리작용을 기대하기는 힘든 실정 이다 $(3,4)$. 식품의약품안전처에서 혈압이 높은 사람에게 도 움을 줄 수 있는 개별인정원료로 L-glutamic acid 유래로 생성된 $\mathrm{GABA}$ 물질이 인정됨에 따라 최근 $\mathrm{GABA}$ 함량을 증진시키기 위해 다양한 미생물을 이용한 발효 방법이 활발 히 연구되고 있다(5)

목이버섯 Auricularia auricula-judae(AAJ)은 다른 버섯 및 식품들에 비해 월등히 많은 식이섬유를 함유하고 있어서 영지버섯 자실체 추출물과 함께 식품의약품안전처에서 배 변활동에 원활한 도움을 주는 건강기능성 원료로 등재되어 있다. 또한 vitamin $\mathrm{D}$ 의 함량도 풍부하며 장내 $\mathrm{Ca}$ 흡수 및 신장에서 $\mathrm{Ca}$ 의 재흡수를 증가시키고 조골세포의 분화를 자극하는 것으로 알려져 있다(6). 각종 약리작용에 의한 민간요법제 등 다양한 용도로 이용되어 왔다(7). 
염증에 관여하는 주요 세포는 macrophage로 알려져 있으 며, 자극이나 면역세포들이 분비하는 사이토카인 등에 의 해 활성화되어(8), proinflammatory cytokine, nitric oxide (NO)와 prostagladin E2(PGE2)를 생성함으로서 통증, 혈관 투과성, 열, 부종 등의 염증반응을 유발하고, 면역세포의 이동을 촉진시킨다(9). 그 중 $\mathrm{NO}$ 는 건강과 질병에 관여하는 자유라디칼 성분이며(10), 이는 L-arginine으로부터 NO synthase (NOS)에 의해 합성된다. NOS 중 inducible NOS (iNOS)는 lipopolysaccharide(LPS)나 염증성 cytokine 등에 의해 유도되고, $\mathrm{iNOS}$ 에 의해 과다 생성된 $\mathrm{NO}$ 는 염증 반응 을 심화시켜 유전자 변이, 조직의 손상 및 신경 손상 등을 일으키며 $(11,12)$, 관절염, 다발성 경화증 및 천식 등의 만성 염증질환이나 당뇨병 및 심혈관 질환 등의 각종 질병을 발생시키는 것으로 보고되어 있다(13).

녹각(old antler, Cornu cerv)은 녹과에 속한 매화록 (Cervus nippon termminok의 털이 없고 골화되어 자연 탈락 하는 각(角, old antler)을 일컫는다(14). 녹각은 발육촉진작 용, 조혈작용, 강심작용 등의 약리작용이 있고(15), 면역기 능과 간장 해에 대한 영향(16-18), 그리고 골다공증(19)에 대한 연구가 진행되었다. 또한 젖산 발효 및 곰팡이발효를 통해 기존 한약재의 약효를 증가시키는 것으로 보고되고 있다(20-22). 한편, 녹용에 비해 저렴한 녹각을 이용한 건강 제품의 개발이 필요하며, 특히 발효를 통한 기능성을 강화 시킨 소재의 개발에 대한 연구는 미비한 실정이다.

따라서 본 연구는 녹용의 부산물인 녹각 및 목이버섯을 이용한 고부가가치 건강식품소재 개발을 위해서 젖산발효 의 최적화를 수행하였다. 이를 위하여 유용 젖산균을 이용 하여 기존 녹각이 가지고 있는 효능과 더불어 젖산 발효를 통해서 생리활성물질이 강화된 기능성 소재를 개발하였으 며, 대식세포를 이용한 세포독성과 염증완화 효능평가를 수행하였다.

\section{재료 및 방법}

\section{재 료}

본 실험에 사용한 녹각(Cervi cornu)은 2014년 보광약업 사(Daegu, Korea)에서 구입하여 사용하였고, 목이버섯 (Auricularia auricula-judae)은 2015년 자연그대로(Daegu, Korea)에서 구입하여 사용하였다.

\section{스타터배양}

미강으로부터 분리하여 종균협회에 기탁한 $\mathrm{GABA}$ 생산 균주인 Lactobacillus plantarum EJ2014(KCCM 11545P)를 이용하여 젖산발효를 수행하였다. L plantarum EJ2014를 Difco ${ }^{\mathrm{TM}}$ Lactobacilli MRS broth agar(Becton, Dickinson and Company, Sparks, MD, USA)배지에 도말한 후, $30^{\circ} \mathrm{C}$ 항온배
양기 IS-971R(Jeio Tech. Kimpo, Korea)에서 24시간 배양 하였다. 그 다음 단일 콜로니를 취하여 2회 계대배양한 후, $121^{\circ} \mathrm{C}$ 에서 15 분간 멸균한 MRS broth에 L plantarum $\mathrm{EJ} 2014$ 를 한 백금이 접종하여, $30^{\circ} \mathrm{C}$ 에서 24 시간 배양하여 스타터로 사용하였다.

녹각 및 목이버섯 추출물의 젖산발효

녹각을 세척한 후, 녹각 $5 \%(\mathrm{w} / \mathrm{w})$ 를 증류수에 첨가하여 한약추출기를 이용하여 추출을 진행하였다. 추출액은 농축 과정 없이 시료로 사용되었으며, GABA 생산을 위한 젖산 발효는 추출물 $100 \mathrm{~mL}$ 에 목이버섯 0-2.5 g 농도별로 첨가하 였고, 미생물의 탄소원인 glucose를 $1.5 \mathrm{~g}$, 질소원 YE 0.5 $\mathrm{g}$ 첨가하였다. GABA생성 전구물질인 MSG $3.5 \mathrm{~g}$ 첨가 후, $121^{\circ} \mathrm{C}$ 에서 15 분간 멸균하였으며 L. plantarum EJ2014 starter $1 \%(\mathrm{v} / \mathrm{v})$ 를 접종하여 $30^{\circ} \mathrm{C}$ 항온배양기에서 7 일간 발 효하였으며, $6 \mathrm{mg} / \mathrm{mL}$ 농도의 발효물을 이용하여 분석에 사용하였다.

\section{녹각 및 목이버섯 발효물의 이화학적 분석}

$\mathrm{pH}$ 는 $\mathrm{pH}$ meter(model 420+, Thermo Orion, USA)로 측정 하였다. 적정 산도는 시료 $1 \mathrm{~mL}$ 에 증류수 $9 \mathrm{~mL}$ 을 첨가하여 $0.1 \mathrm{~N} \mathrm{NaOH}$ 를 이용해 $\mathrm{pH} 8.3$ 까지 적정한 소비량을 젖산 함량 $(\%, \mathrm{v} / \mathrm{v})$ 으로 환산하였다.

생균수는 발효물 $1 \mathrm{~mL}$ 에 멸균수 $9 \mathrm{~mL}$ 을 첨가하여 10 배 희석법을 이용하여 $10^{4}, 10^{5}, 10^{6}$ 배로 희석된 것을 MRS agar plate에 $20 \mu \mathrm{L}$ 도말한 후, $30^{\circ} \mathrm{C}$ 항온배양기에서 48 시간 배양한 후 생균수를 colony forming unit(CFU)/mL으로 나타 내었다(23).

Thin layer chromatography (TLC) 분석

MSG 및 GABA의 정성 분석을 위해 silica gel TLC plate는 $10 \times 20 \mathrm{~cm}$ 의 크기로 잘라서 사용하였고, TLC 전개는 사각 chamber $(30 \times 25 \times 10 \mathrm{~cm})$ 에서 수행하였다(24). MSG 잔존량 과 GABA 함량 비교를 위한 standard로 MSG $0.5-2 \%$ 와 GABA 0.5-1\%를 사용하였다. 전개용매는 acetic acid glacial:n-butylalcohol:distilled water를 1:3:1(v/v)의 비율로 혼합하여 실온에서 3 시간 이상 포화시켰다. 발효물은 증류 수로 2 배 희석한 후 각각 시료와 standard 용액을 TLC plate 의 아래에서 $15 \mathrm{~mm}$ 되는 위치에 $2 \mu \mathrm{L}$ 를 점적하였고, 간격은 10-15 mm를 유지하였다. 점적 후 TLC plate의 sample을 건조한 다음 전개하였고, 전개가 끝난 TLC plate는 $50^{\circ} \mathrm{C}$ 감압건조기에서 건조시킨다. 건조된 TLC plate에 발색시약 인 $0.2 \%$ ninhydrin 용액을 뿌리고, $100^{\circ} \mathrm{C}$ 감압건조기에서 5-10분 동안 발색 시킨 후 발효물의 glutamic acid와 GABA spot을 확인하였다.

High performance liquid chromatography (HPLC) 분석 유리 아미노산 함량 측정은 건조시킨 시료를 실온에서 
30 분 동안 유도체화 하여 건조시킨 후 $\mathrm{A}$ 용매 $(140 \mathrm{mM}$ $\mathrm{NaHAc}, 0.1 \%$ triethanolamine, $6 \% \mathrm{CH}_{3} \mathrm{CN}, \mathrm{pH}$ 6.1)와 함께 혼합하여 원심분리 하였다(25). 상등액을 $0.45 \mu \mathrm{m}$ syringe filter로 여과하여 분석시료로 사용하였으며 HPLC 분석에 사용된 조건과 용매는 각각 A 용매 $100 \%$ 로 elution후 25 분 동안 $\mathrm{B}\left(60 \% \mathrm{CH}_{3} \mathrm{CN}\right) 100 \%$ 가 되도록 혼합하면서 분당 1 $\mathrm{mL}$ 로 흘려주었다. 아미노산 측정은 $254 \mathrm{~nm}$ 에서 $\mathrm{UV}$ 흡광 도를 측정하였다.

\section{총 폴리페놀 함량 측정}

총 폴리페놀 함량은 $\mathrm{AOAC}$ 법에 의하여 측정하였다(26). 시료를 5 배로 희석한 다음 $60 \mu \mathrm{L}$ 을 취하여 2 배 희석한 Folin 시약을 $60 \mu \mathrm{L}$ 를 가하여 3 분간 방치한 후 $10 \% \mathrm{Na}_{2} \mathrm{CO}_{3}$ 용액 $60 \mu \mathrm{L}$ 를 가하여 반응시켜 반응액의 흡광도를 $700 \mathrm{~nm}$ 에서 측정하였다. 표준곡선은 gallic acid를 $0,20,40,60,80,100$ $\mu \mathrm{g} / \mathrm{mL}$ 용액이 되도록 조제하고, 이를 일정량 취하여 위와 같은 방법으로 $700 \mathrm{~nm}$ 에서 흡광도를 측정하여 계산하였다.

\section{총 플라보노이드 함량 측정}

시료 중의 총 플라보노이드 함량은 Nieva Moreno등(27) 의 방법을 이용하여 측정하였다. 시료 $0.5 \mathrm{~mL}$ 에 $10 \%$ aluminium nitrate와 $1 \mathrm{M}$ potassium acetate를 각각 $0.1 \mathrm{~mL}$, $80 \%$ ethanol $4.3 \mathrm{~mL}$ 을 가하여 실온에 40 분 방치한 뒤 415 $\mathrm{nm}$ 에서 흡광도를 측정하였다. 표준물질 quercetin을 0,20 , $40,60,80,100 \mu \mathrm{g} / \mathrm{mL}$ 용액이 되도록 조제하고 이를 일정량 취하여 위와 같은 방법으로 $415 \mathrm{~nm}$ 에서 흡광도를 측정하여 계산하였다.

a-a-Diphenyl- $\beta$-picrylhydrazyl(DPPH) free radical 소거 활성측정

녹각 추출물 젖산 발효물의 free radical 소거 활성은 $\mathrm{DPPH}$ 에 대한 환원력을 측정한 것(27)으로 시료 $160 \mu \mathrm{L}$ 와 에탄올에 녹인 $0.15 \mathrm{mM} \mathrm{DPPH}$ 용액 $40 \mu \mathrm{L}$ 를 가하여 실온에 서 30 분 방치한 후 $517 \mathrm{~nm}$ 에서 흡광도를 측정하였다. 각 시료의 free radical 소거 활성은 시료를 첨가하지 않은 대조 구의 흡광도를 $1 / 2$ 로 환원시키는데 필요한 시료의 농도인 $\mathrm{IC}_{50}$ 값으로 나타내었다. 이 때 상대 활성의 비교를 위하여 대조군으로 trolox를 사용하였다.

2,2'-Azino-bis (3-ethylbenzothiazoline-6-sulph onic acid) radical(ABTS +·) 소거 활성 측정

$\mathrm{ABTS}$ radical 소거활성 측정 실험은 $\operatorname{Re}$ 등(28)의 방법을 변형하여 측정하였다. 최종 농도 $7 \mathrm{mM} \mathrm{2,2-azino-bis(3-}$ ethylbenzthiazoline-6-sulfonic acid)와 $2.45 \mathrm{mM}$ potassium persulfate를 혼합하여 실온인 암소에서 24시간 동안 반응하 여 $\mathrm{ABTS}+$ 를 형성시킨 후 $732 \mathrm{~nm}$ 에서 흡광도 값이 $0.70 \pm 0.02$ 이 되게 phosphate 완충액 식염수(phosphate buffer saline; PBS, pH 7.4)로 희석하였다. 희석된 용액 $180 \mu \mathrm{L}$ 에 희석된 시료를 $20 \mu \mathrm{L}$ 를 가하여 정확히 1 분 동안 반응 후 흡광도를 측정하였다. Free radical 소거 활성은 시료를 첨가 하지 않은 대조구의 흡광도를 $1 / 2$ 로 환원시키는데 필요한 시료의 농도인 $\mathrm{IC}_{50}$ 값으로 나타내었다. 이 때 상대 활성의 비교를 위하여 대조군으로 trolox를 사용하였다.

\section{RAW 264.7 대식 세포 배양}

마우스 유래 대식세포주인 RAW 264.7 세포는 한국세포 주은행(KCLB)에서 분양을 받았으며 세포배양을 위해 $10 \%$ fetal bovine serum(FBS)와 $1 \%$ antibiotics (penicillin)를 첨가 한 $\mathrm{DMEM}$ 배지를 이용하여 $5 \% \mathrm{CO}_{2}$ 가 존재하는 $37^{\circ} \mathrm{C}$ incubator에서 1 주일에 2, 3회 계대배양을 실시하였다.

\section{세포 생존율 측정}

세포에 대한 독성 여부를 알아보기 위해 Green 등(29)의 방법에 따라 3-(3,4-dimethyl-thiazolyl-2)-2,5-diphenyl tetrazolium bromide (MTT) assay 방법을 이용하여 측정하였다. MTT assay는 미토콘드리아의 탈수소 효소작용에 의하여 노란색 의 수용성 기질인 MTT가 불용성의 보라색 formazan으로 환원되는 원리를 이용한 방법으로, 생성된 formazan의 흡광 도는 살아있거나 대사가 왕성한 세포의 농도를 반영 한다 (30). 배양된 대식 세포주를 $1 \times 10^{5}$ cells/well의 농도로 96 well plate에 분주하여 $5 \% \mathrm{CO}_{2}$ incubator에서 24시간 동안 배양한 후 시료를 농도별로 처리하여 24시간 배양한 세포 에 PBS에 녹인 MTT $(5 \mathrm{mg} / \mathrm{mL})$ 용액 $10 \mu \mathrm{L}$ 를 각 well에 넣고 incubator에서 4시간 동안 반응시킨다. 배양 종료 후 상등액을 제거하고, 각 well에 $100 \mu \mathrm{L}$ 의 dimethyl sulfoxide (DMSO)를 첨가하여 생성된 formazan crystal을 용해시켜 $550 \mathrm{~nm}$ 파장에서 microplate reader(Epoch, BioTek, USA)로 흡광도를 측정하였다. 세포생존율은 시료를 처리하지 않고 세포만 배양한 무처리군의 $100 \%$ 생존율을 기준으로 상대 적인 세포생존율(cell viability, \%)을 계산하였다.

$$
\text { Cell viability }(\%)=\left(\frac{\text { 시료 처리군의 흡광도 }}{\text { 대조군의 흡광도 }}\right) \times 100
$$

\section{Nitric oxide(NO) 생성량 측정}

$\mathrm{NO}$ 의 농도는 배양액 내의 nitrite 농도를 Griess Reagent System(31)의 방법을 이용하여 측정하였다. RAW 264.7 세 포를 $1 \times 10^{5}$ cells/well의 농도로 96 well plate에 분주 후 $37^{\circ} \mathrm{C}$, $5 \% \mathrm{CO}_{2}$ incubator를 이용하여 24시간 동안 배양하였다. 배 양 후 시료를 농도별로 처리한 후, 24시간 동안 배양하여 배양 상등액 $100 \mu \mathrm{L}$ 를 새로운 96 well plate에 취하고 여기에 동량의 Griess 시약( $1 \%$ sulfanilamide, $0.1 \%$ naphthylethylendiamine in $2.5 \%$ phosphoric acid)을 첨가하여 10 분간 반응 후 microplate reader(Epoch, BioTek, USA)를 이용하여 $540 \mathrm{~nm}$ 
의 흡광도로 측정하였다. Nitrite의 농도 $(\mu \mathrm{M})$ 는 sodium nitrite $\left(\mathrm{NaNO}_{2}\right)$ 를 사용하여 얻은 표준 직선과 비교하여 산출 하였다.

\section{통계처리}

실험결과는 평균값과 표준편차 $(m e a n \pm S D)$ 로 나타내었 으며, 통계처리는 SPSS(statistical package for social science, 21.05, SPSS Inc., Chicago, IL, USA)를 이용하여 one-way ANOVA 분석을 실시한 후 Duncan's multiple range test로 유의성을 $\mathrm{p}<0.05$ 수준에서 검증하였다.

\section{결과 및 고찰}

목이버섯 첨가에 따른 젖산발효물의 이화학적 분석

녹각을 한약추출기를 이용하여 추출 후 $3.5 \% \mathrm{MSG}, 1.5 \%$ glucose, $0.5 \%$ YE 첨가한 후 젖산발효 했을 때 GABA 생성 이 가장 우수한 것으로 나타났다. GABA 생성 최적조건에 서 목이버섯을 0-2.5\% 첨가하여 젖산발효를 진행했을 때, $\mathrm{pH}$ 및 산도를 측정한 결과는 Fig. 1에 나타내었다. 목이버섯 $0 \%, 2.5 \%$ 조건에서 발효 0 일 각각 $\mathrm{pH} 6.15, \mathrm{pH} 5.91$ 이였고 발효 1 일 $\mathrm{pH} 4.30, \mathrm{pH} 4.20$ 으로 젖산발효가 진행됨에 따라 떨어졌다. 목이버섯 농도 $0 \%$ 조건에서 발효 3 일 $\mathrm{pH} 4.2$ 에서 발효 7일 $\mathrm{pH} 4.35$ 로 유지되었고, 목이버섯 농도 $2.5 \%$ 조건 에서 발효 3일 $\mathrm{pH} 4.59$ 에서 발효 7일 $\mathrm{pH}$ 5.06으로 증가되었 다. 산도의 결과 발효 0 일 각각 $0.13 \%, 0.05 \%$ 였으며, 목이버 섯 $0 \%$ 조건에서 발효 1 일 $1.08 \%$ 로 급격히 증가하여 발효 7일 $0.31 \%$ 로 감소하였다. 목이버섯 $2.5 \%$ 조건에서 발효 3 일 $0.95 \%$ 로 급격히 증가하였고 발효 7일 $0.77 \%$ 로 감소하 는 것으로 나타났다. $\operatorname{Lim}, \operatorname{Kim}(32,33)$ 에 따르면 이는 미생

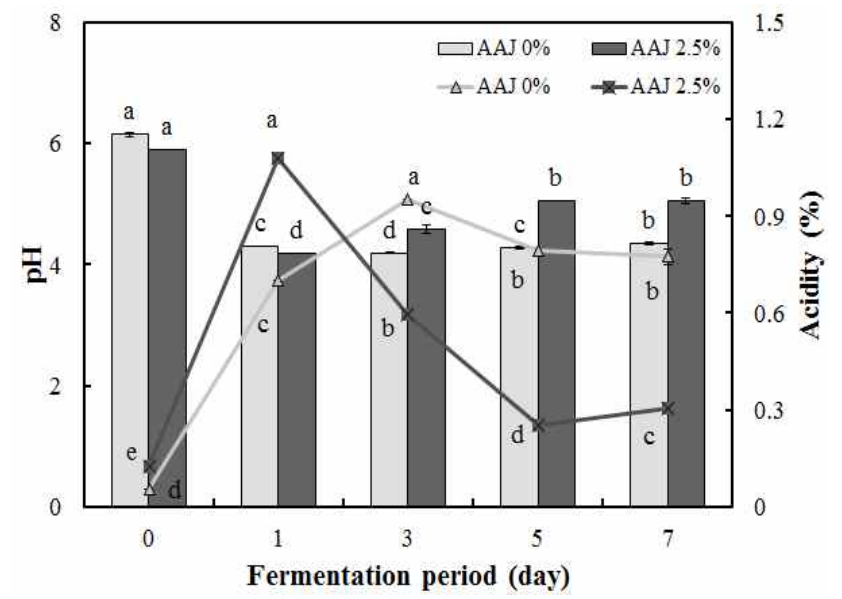

Fig. 1. Effect of Auricularia auricula-judae (AAJ) on $\mathrm{pH}$ and acidity of the lactic acid fermented old antler extract (OAE).

Data represent the mean \pm SD ( $n=3$ ). Different letters indicate significant differences at $p<0.05$ by Duncan's multiple range test.
물에 의한 GABA가 생성될 때 glutamate decarboxylase (GAD)에 의한 glutamate가 GABA로 전환될 때 proton이 소비됨으로써 $\mathrm{GABA}$ 의 생성과 더불어 $\mathrm{pH}$ 를 증가시키는 것으로 보고하였다. 따라서 젖산균 발효에 의해 GABA가 생성되면서 $\mathrm{pH}$ 가 유지되거나 상승하는 결과로 보아 MSG 가 GABA로 전환되는 것으로 사료된다. 젖산균 생균수를 측정한 결과는 Fig. 2 에서 보는바와 같이 녹각 추출물의 목이버섯 첨가에 따른 젖산발효를 수행하였을 때, 발효 1 일 각각 $8.0 \times 10^{8} \mathrm{CFU} / \mathrm{mL}, 4.5 \times 10^{9} \mathrm{CFU} / \mathrm{mL}$ 로 균수가 급격히 상승하였고, 목이버섯 $2.5 \%$ 조건에서 균수가 가장 높게 나타났다. 발효 3 일 $1.5 \times 10^{9} \mathrm{CFU} / \mathrm{mL}, 1.9 \times 10^{9} \mathrm{CFU} / \mathrm{mL}$ 에서 발효 7일째 각각 $1.9 \times 10^{8} \mathrm{CFU} / \mathrm{mL}, 1.3 \times 10^{8} \mathrm{CFU} / \mathrm{mL}$ 로 발효 시간이 지남에 따라 약간 감소하는 것으로 나타났으나 높은 생균수를 유지하였다.

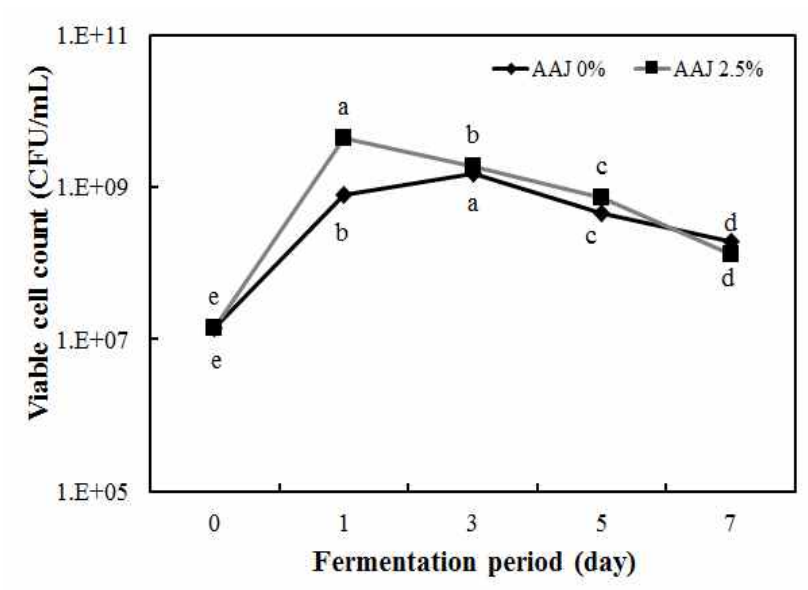

Fig. 2. Effect of Auricularia auricula-judae (AAJ) on viable cell counts of the lactic acid fermented old antler extract (OAE).

Data represent the mean \pm SD ( $n=3$ ). Different letters indicate significant differences at $\mathrm{p}<0.05$ by Duncan's multiple range test.

\section{$\mathrm{GABA}$ 분석}

Fig. 3에 나타낸 것처럼 TLC를 이용하여 정성 분석을 했을 때 목이버섯 농도 $0 \%$ 조건에서 발효 3일째 GABA spot이 생성되었으며 발효 5일째 MSG가 약간 잔존하였고, 발효 7일째 $\mathrm{MSG}$ 가 모두 GABA로 전환되는 것으로 나타났 다. 목이버섯 농도 $2.5 \%$ 조건에서 발효 1 일째 GABA spot이 나타났고 발효 3일째 MSG spot이 작아지면서 발효 5일째 $\mathrm{MSG}$ 가 $\mathrm{GABA}$ 로 모두 전환되었다. 목이버섯 농도 $0 \%$ 조건 에서 $\mathrm{MSG}$ 가 GABA로 7일째 전환 되었으나 목이버섯 농도 $2.5 \%$ 에서 5 일째 모두 전환되어 약 $1 \%$ 이상 $\mathrm{GABA}$ 가 생성 되었다. 따라서 목이버섯 첨가가 젖산발효를 통한 단기간 에 GABA 생성에 영향을 주는 것으로 사료되었다. HPLC를 이용하여 glutamic acid와 GABA를 정량 분석하였다. 목이 버섯 $0 \%$ 조건에서 glutamic acid 함량은 발효 전 19,499 $\mu \mathrm{g} / \mathrm{mL}$ 에서 젖산균발효 후 $4,835 \mu \mathrm{g} / \mathrm{mL}$ 로 감소하였으며, 
$\mathrm{GABA}$ 함량은 젖산발효 후 $14,328 \mu \mathrm{g} / \mathrm{mL}$ 로 생성되는 것을 확인하였다. 목이버섯 $2.5 \%$ 조건에서 glutamic acid 함량은 발효 전 $19,916 \mu \mathrm{g} / \mathrm{mL}$ 에서 젖산발효 후 $1,586 \mu \mathrm{g} / \mathrm{mL}$ 로 감소 하였으며, GABA 함량은 젖산균 발효 후 $14,446 \mu \mathrm{g} / \mathrm{mL}$ 로 생성되는 것을 확인하였다. 초기에 첨가된 $3.5 \% \mathrm{MSG}$ 는 이온화되어 $1.9 \%$ glutamic acid로 분석되었고, 젖산발효를 통해서 감소되면서 $0.45 \%$ glutamic acid가 잔존하면서 $\mathrm{GABA}$ 전환율이 $76 \%$ 를 나타내었다. 미생물에 의한 $\mathrm{GABA}$ 의 생산으로 B. subtilis $\mathrm{M} 31$ 과 L. sakei 383 를 혼합 발효한 청국장에서 $0.47 \pm 0.0027 \mathrm{mg} / \mathrm{g}$ 으로 나타났으며(34), 우유를 이용한 고초균과 젖산균의 혼합발효에서 $0.18 \mu \mathrm{gg} / \mathrm{mL}$ 생성 되었다(35). 따라서 젖산균을 이용한 단일 발효를 통해 단기 간에 $1 \%$ 이상의 $\mathrm{GABA}$ 를 생성함으로써 고농도 $\mathrm{GABA}$ 를 함유한 녹각 추출물 발효물을 생산할 수 있었다.
발효 전, 후의 플라보노이드 함량은 목이버섯 $2.5 \%$ 조건에 서 발효 전 $18.25 \mathrm{mg} / \mathrm{mL}$ 에서 발효 후 $13.69 \mathrm{mg} / \mathrm{mL}$ 로 감소 하였다. $\operatorname{Kang}(36)$ 의 연구에서 한약재의 종류에 따른 총 플 라보노이드 함량은 금은화 $21 \mathrm{mg} / \mathrm{mL}$, 옻나무 $18 \mathrm{mg} / \mathrm{mL}$, 구지뽕 $10 \mathrm{mg} / \mathrm{mL}$, 상백피 $7 \mathrm{mg} / \mathrm{mL}$, 포공영 $5 \mathrm{mg} / \mathrm{mL}$, 도인 총 $3 \mathrm{mg} / \mathrm{mL}$ 로 나타났으며, 다른 한약재의 함량 결과와 유사 하게 나타났다(Table 2).

a-a-Diphenyl- $\beta$-picrylhydrazyl(DPPH) free radical 소거활성 측정

목이버섯 $2.5 \%$ 조건에서 발효 전 $0.12 \mathrm{mg} / \mathrm{mL}$ 에서 발효 후 $0.16 \mathrm{mg} / \mathrm{mL}$ 로 발효에 따른 radical 소거활성은 차이가 없음을 확인할 수 있었다. Lee등(37)은 뉴질랜드산 녹용 상대를 열탕 추출하여 DPPH 라디칼 소거 활성을 측정한

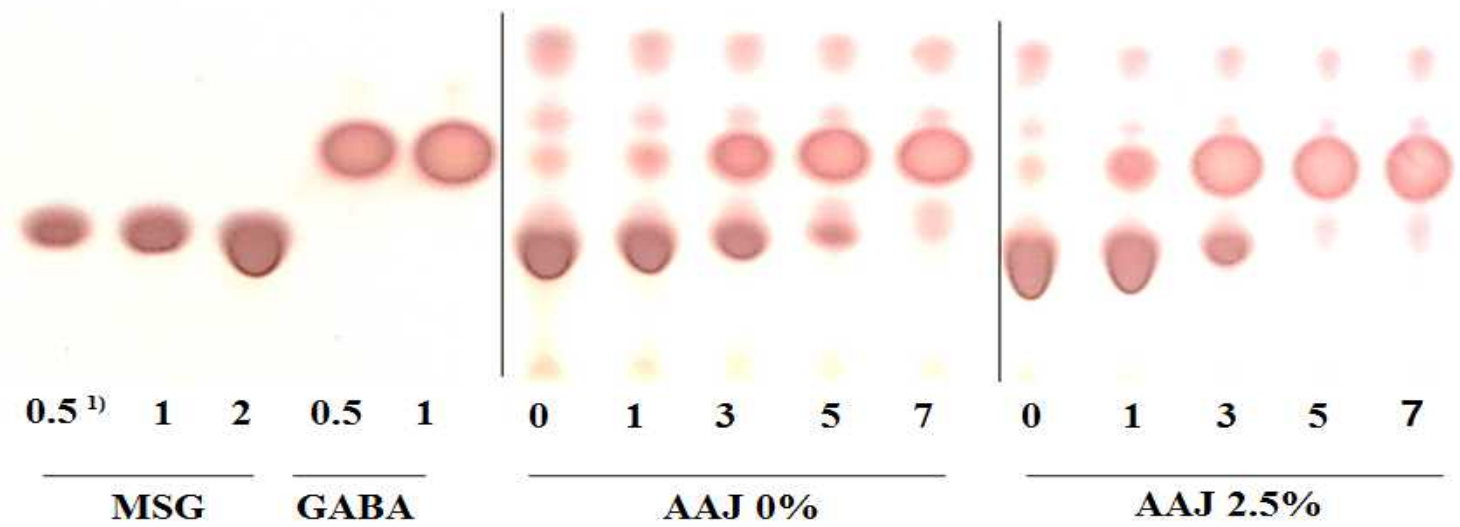

Fig. 3. TLC profile of GABA in lactic acid fermented old antler extract (OAE) with Auricularia auricula-judae (AAJ).

${ }^{1}$ Fermentation period (day).

\section{총 폴리페놀 함량}

젖산발효 녹각의 기준물질로 gallic acid를 사용했으며, 발효 전, 후의 폴리페놀 함량은 목이버섯 $2.5 \%$ 조건에서 발효 전 $19.40 \mathrm{mg} / \mathrm{mL}$, 발효 후 $22.55 \mathrm{mg} / \mathrm{mL}$ 로 약간증가하 였다. 젖산발효 녹각의 기준물질로 quercetin을 사용했으며

Table 1. Changes in content of glutamic acid and GABA during fermentation

$(\mu \mathrm{g} / \mathrm{mL})$

\begin{tabular}{cccc}
\hline \multirow{2}{*}{$\mathrm{AAJ}^{\mathrm{1}}{ }^{2}$} & $\begin{array}{c}\text { fermentation } \\
\text { period (day) }\end{array}$ & Glutamic acid & GABA \\
\hline \multirow{2}{*}{$0 \%$} & 0 & $19,499 \pm 51.75^{2)}$ & 0 \\
& 7 & $4,835 \pm 41.27$ & $14,328 \pm 55.21$ \\
\hline \multirow{2}{*}{$2.5 \%$} & 0 & $19,916 \pm 61.22$ & 0 \\
& 7 & $1,586 \pm 45.85$ & $14,446 \pm 54.22$ \\
\hline
\end{tabular}

\footnotetext{
${ }^{1)}$ AAJ, Auricularia auricula-judae.

${ }^{2)}$ Data represent the mean $\pm S D(n=3)$.
}

Table 2. Total polyphenol content of old antler extract (OAE) fermented with Auricularia auricula-judae (AAJ)

\begin{tabular}{ccc}
\hline & \multicolumn{2}{c}{ Fermentation period (day) } \\
\cline { 2 - 3 } & 0 & 7 \\
\hline Polyphenol content $(\mathrm{mg} / \mathrm{mL})$ & $19.40 \pm 1.07^{1)}$ & $22.55 \pm 1.05$ \\
Flavonoid content $(\mathrm{mg} / \mathrm{mL})$ & $18.25 \pm 0.02$ & $13.69 \pm 0.28$ \\
\hline
\end{tabular}

${ }^{1)}$ Data represent the mean \pm SD $(n=3)$.

결과 $100 \mathrm{mg} / \mathrm{mL}$ 농도에서 $67.1 \%$ 의 소거 활성을 나타낸다 고 하였다. 또한 녹용 함량이 약 $70 \mathrm{mg} / \mathrm{mL}$ 정도 함유하는 녹용대보탕의 항산화 활성이 $0.9 \%$ 였다는 Lee등(38)의 보 고와 비교할 때 한약탕제의 생약 성분들이 중요한 항산화 역할을 하는 것으로 추정된다. 따라서 본 연구에서 열수 추출법을 사용함으로써 많은 생리활성 물질이 추출되었음 을 알 수 있었다(Table 3). 
Table 3. Scavenging effect of trolox and old antler extract (OAE) fermented with Auricularia auricula-judae (AAJ) against a- a -Diphenyl- $\beta$-picryhydrazyl (DPPH•)

\begin{tabular}{ccc}
\hline \multicolumn{2}{c}{ Fermentation period (day) } & $\mathrm{IC}_{50}{ }^{1)}(\mathrm{mg} / \mathrm{mL})$ \\
\hline \multirow{2}{*}{ AAJ 2.5\% } & 0 & $0.12 \pm 0.01^{2)}$ \\
& 7 & $0.16 \pm 0.03$ \\
\hline \multicolumn{2}{c}{ Trolox } & $3.25 \mu \mathrm{g} / \mathrm{mL}$ \\
\hline
\end{tabular}

${ }^{1)}$ Concentration required for $50 \%$ reduction of DPPH· at $30 \mathrm{~min}$ after starting the reaction.

${ }^{2)}$ Data represent the mean $\pm \mathrm{SD}(\mathrm{n}=3)$.

2,2'-Azino-bis(3-ethylbenzothiazoline-6-sulph onic acid) radical(ABTS $+\cdot$ ) 소거활성 측정

목이버섯 $2.5 \%$ 조건에서 발효 전 $2.62 \mathrm{mg} / \mathrm{mL}$ 에서 발효 후 $2.71 \mathrm{mg} / \mathrm{mL}$ 로 발효에 따른 radical 소거활성은 차이가 없음을 확인할 수 있었다(Table 4).

Table 4. Scavenging effect of trolox and old antler extract (OAE) fermented with Auricularia auricula-judae (AAJ) against 2,2-azino-bis (3-ethylbenzthiazoline-6-sulfonic acid) radical (ABTS+•)

\begin{tabular}{ccc}
\hline \multicolumn{2}{c}{ Fermentation period (day) } & $\mathrm{IC}_{50}{ }^{1)}(\mathrm{mg} / \mathrm{mL})$ \\
\hline \multirow{2}{*}{ AAJ $2.5 \%$} & 0 & $2.62 \pm 0.03^{2)}$ \\
& 7 & $2.71 \pm 0.07$ \\
\hline \multicolumn{2}{c}{ Trolox } & $5.28 \mu \mathrm{g} / \mathrm{mL}$ \\
\hline
\end{tabular}

${ }^{1)}$ Concentration required for $50 \%$ reduction of $\mathrm{ABTS}+\cdot$ at $3 \mathrm{~min}$ after starting the reaction.

${ }^{2)}$ Data represent the mean $\pm \mathrm{SD}(\mathrm{n}=3)$.

\section{세포생존율}

목이버섯 발효 전 $6 \mathrm{mg} / \mathrm{mL}$ 에서 세포독성이 나타났고, 발효 후 $80 \%$ 이상의 세포 생존율로 나타났다(Fig. 4). $\operatorname{Kim}(39)$ 의 연구에서 대황과 발효대황 물 추출물의 0.1-1 $\mathrm{mg} / \mathrm{mL}$ 농도에서 세포생존율을 측정하였을 때, 대황은 1 $\mathrm{mg} / \mathrm{mL}$ 에서 세포독성이 나타났으며, 발효대황은 모든 농도 구간에서 세포독성이 나타나지 않았다. 마찬가지로 젖산발 효를 통해서 발효물의 세포독성이 완화되는 것으로 판단되 었다.

\section{$\mathrm{NO}$ 소거활성}

대식세포는 lipopolysaccharide(LPS)에 의해 자극될 때 iNOS가 발현되어 NO을 생성하게 되는데 이렇게 생성된 $\mathrm{NO}$ 는 염증반응을 매개하는 역할을 하게 된다(40). 따라서 목이버섯 $2.5 \%$ 조건에서 대조군, LPS에 의한 양성대조군 각각 $1.1 \mu \mathrm{M}, 34.1 \mu \mathrm{M}$ 이였고 발효 전 $4 \mathrm{mg} / \mathrm{mL}$ 농도에서 $24.01 \mathrm{\mu M}$ 로 감소하였으며, $6 \mathrm{mg} / \mathrm{mL}$ 농도에서는 대조군과 동일하게 $\mathrm{NO}$ 생성이 저해되는 것으로 나타났으나, 세포독 성으로 인해 NO 생성이 저해되는 것으로 사료된다. 발효 후 $4 \mathrm{mg} / \mathrm{mL}$ 농도에서 $17.75 \mu \mathrm{M}$ 로 감소하였으며, $6 \mathrm{mg} / \mathrm{mL}$

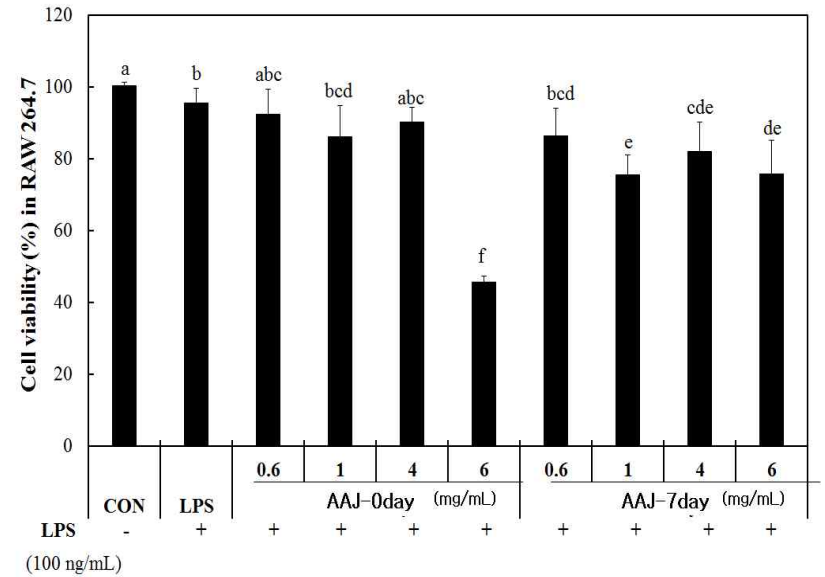

Fig. 4. Effect of old antler extract(OAE) fermented with Auricularia auricula-judae(AAJ) on RAW 264.7 cell viability.

Data represent the mean $\pm \mathrm{SD}(\mathrm{n}=3)$. Different letters indicate significant differences at $\mathrm{p}<0.05$ by Duncan's multiple range test.

농도에서는 $5.58 \mu \mathrm{M}$ 로 발효 후 $\mathrm{NO}$ 생성이 감소되는 것으로 나타났다(Fig. 5). 따라서 $4 \mathrm{mg} / \mathrm{mL}$ 농도에서 발효 후의 $\mathrm{NO}$ 생성량이 낮은 것을 알 수 있었다. Tak 등(41)은 흑마늘 발효물이 LPS 유무에 관계없이 모두 대식세포의 NO 생성 을 유의적으로 억제하였는데, 이 결과는 흑마늘 발효물이 염증반응 억제에 효과가 있음을 의미한다고 보고한 바 있 다. 이는 본 연구의 결과에서도 동일한 경향으로 녹각 젖산 발효물은 외부의 자극으로부터 유도되는 NO 생성을 효과 적으로 감소시킬 수 있음을 확인하였다.

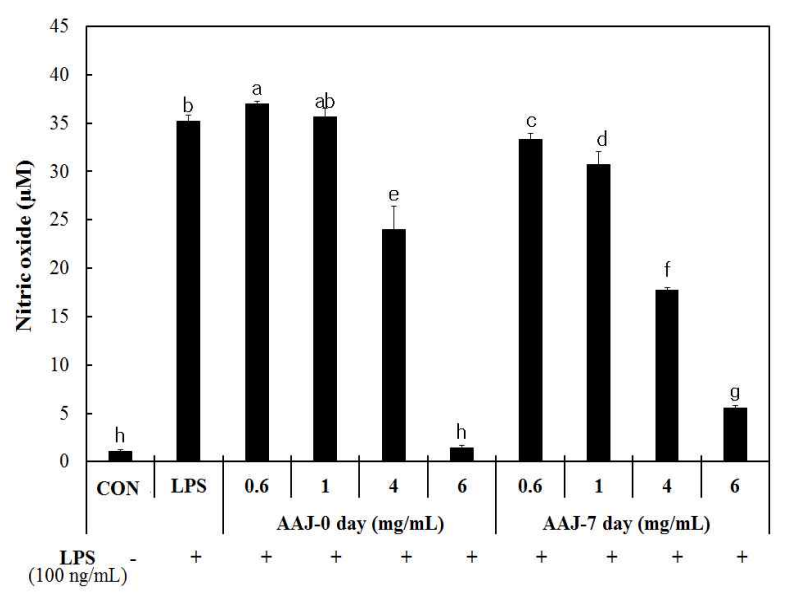

Fig. 5. Effect of old antler extract (OAE) fermented with Auricularia auricula-judae (AAJ) on NO production.

Data represent the mean $\pm S D(n=3)$. Different letters indicate significant differences at $\mathrm{p}<0.05$ by Duncan's multiple range test.

\section{요 약}

본 연구에서는 젖산발효를 통해서 얻어진 목이버섯과 녹각 추출액 혼합물의 항산화 및 생리활성평가를 수행하였 
다. 녹각 추출액의 GABA생성 최적조건에서 probiotics 및 기능성 강화를 위해 목이버섯을 $2.5 \%$ 첨가하여 $30^{\circ} \mathrm{C}$ 에서 7일간 젖산발효를 하였다. 발효 7일 $\mathrm{pH} 5.06$, 산도 $0.77 \%$ 로 나타났으며 $1.3 \times 10^{8} \mathrm{CFU} / \mathrm{mL}$ 로 높은 균수를 유지하였고 $\mathrm{GABA}$ 를 $1.4 \%$ 생성하는 것으로 나타났다. 목이버섯을 첨 가했을 때 젖산균 발효물의 물성이 개선되며 단기간에 고농 도의 $\mathrm{GABA}$ 를 생성하는 것으로 나타났다. 녹각 추출액의 젖산발효물의 세포 생존율을 실험한 목이버섯 $2.5 \%$ 조건에 서 발효 전 $6 \mathrm{mg} / \mathrm{mL}$ 에서 독성이 나타났으나 발효 후 독성이 완화되는 것으로 나타났다. 발효 후 $6 \mathrm{mg} / \mathrm{mL}$ 농도에서는 $5.58 \mu \mathrm{M}$ 로 발효 후 $\mathrm{NO}$ 생성이 감소되는 것으로 나타났다. 결론적으로 녹각 추출액과 목이버섯 혼합물의 젖산균을 이용한 정치배양을 통해 단기간에 고농도의 GABA 생산이 가능하였으며, 젖산 발효물은 세포독성 완화 효과 및 $\mathrm{NO}$ 생성을 저해하는 것으로 나타났다. 따라서 발효물은 GABA, probiotic, 식이섬유 등을 함유하여 기능성 식품소재 로 이용이 가능할 것으로 기대된다.

\section{감사의 글}

본 결과물은 농림축산식품부의 재원으로 농림수산식품 기술기획평가원의 기술사업화지원사업의 지원을 받아 연 구되었음(No. 314082-3)

\section{References}

1. Han SB, Kim YH (2006) Production method of $\gamma$ -aminobutyric acid-enforced fermentative products by lactic acid bacteria, $z$-aminobutyric acid-enforced fermentative products produced by the method and their utilization. Korea Patent No. 10-0547018

2. Jeun JH, Kim HD, Lee HS, Ryu BH (2004) Isolation and identification of Lactobacillus sp. produced $\mathrm{\gamma}$ -aminobutyric acid (GABA) form traditional slat fermented anchovy. J Korean Soc Food Sci Nutr, 17, $72-79$

3. Bouche N, Fromm H (2004) GABA in plant: just a metabolite?. Trends Plant Sci, 9, 110-115

4. Kang TJ, Oh SH (2007) Produce and using to GABA. Biowave, 9, 3

5. Lee EG (2009) Producing development for GABA industry. Korea research institute of bioscience and biotechnology, 1-57

6. Tsushida T, Murai T (1987) Conversion of glutamic acid to $\gamma$-aminobutyric acid in tea leaves under anaerobic conditions. Agric Biol Chem, 51, 2865-2871

7. Cagno RD, Mazzacane F, Rizzello CG, Angelis MD, Giuliani G, Meloni M, Servi BD, Gobbetti M (2010) SynThesis of y-aminobutyric acid (GABA) by Lactobacillus plantarum DSM19463: functional grape must beverage and dermatological applications. Appl Microbiol Biotechnol, 86, 731-741

8. Lis-Balchin M (1997) Essential oils and aromatherapy: their modem role in healing. J R Soc Health, 117, 324-329

9. Buckle J (1999) Use of aromatherapy as a complementary treatment for chronic pain. Altern Ther Health Med, 5, 42-51

10. Kendall HK, Marshall RI, Bartold PM (2001) Nitric oxide and tissue destruction. Oral Dis, 7, 2-10

11. Lee TH, Kwak HB, Kim HH, Lee ZH, Chung DK, Baek NI, Kim J (2007) Methanol extracts of Stewartia koreana inhibit cyclooxygenase-2 (COX-2) and inducible nitric oxide synthase (iNOS) gene expression by blocking NF-kappa B transactivation in LPS-activated RAW 264.7 cells. Mol Cells, 23, 398-404

12. Ko WM, Lee DS, Jang M, Kim KS, Lee HS, Baek HY, Oh HC, Kim YC (2013) A comparison of anti-inflammatory effects of sophorae flos ethanol extracts at the different flowering stages on LPS-induced inflammation in RAW 264.7 cells. Korean J Pharmacogn, 44, 291-297

13. Park SH, Kim JI, Jeong YK, Choi YH (2011) Extracts of allium fistulosum attenuates pro-inflammatory action in the lipopolysaccharide-stimulated BV2 microglia Cells. J Life Sci, 21, 796-804

14. Han JS (2006) Manual of individual nutrition. Korean association of individual nutrition, $\mathrm{p}$ 78-79

15. Ann YG (2003) A study on overgrown antler Kimchi. J Korean Soc Food Sci Nutr, 16, 123-129

16. Kim YE, Lee SG, Yoon WC (1973) Studies on the components and biological functions of animal hard tissue. A study of a scleroprotein extracted from deer horn. Korean Biochemb J, 6, 13-26

17. Kim MJ (1991) Effect of old antler extracts on the benzo (a)phytene-induced hepatotoxicity in rat. MS Thesis, Yeungnam University, Korea, p 1-2

18. Hwang JS (2010) Effect of cervi cornu on treatment of osteoporosis in ovariectomized rats. MS Thesis, Daegu haany University, Korea, p 1-2

19. Park HI (2017) Comparison of the effects of deer antler, old antler, and antler glue on osteoporosis in ovariectomized rats. Ph D Thesis, Sangji University, Korea, p 1-2 
20. Choi YK, Sul JU, Park SK, Yu SN, Kim SH, Rhee MS, Ahn SC, Shin MS (2012) Research trends of fermented medicinal herbs - Based on their clinical efficacy and safety assessment. J Life Sci, 22, 1729-1739

21. Kim MK, Jung EY, Shin KS, Kim YK, Ra KS, Park CS, Woo MJ, Lee SH, Lee HS, Kim JS, Suh HJ (2009) Isolation of strain for the preparation of the fermented antler and its physiological activities. J Korean Soc Food Sci Nutr, 38, 1237-1242

22. Lee HS, Kim MK, Kim YK, Jung EY, Park CS, Woo MJ, Lee SH, Kim JS, Suh HJ (2011) Stimulation of osteoblastic differentiation and mineralization in MC3T3-E1 cells by antler and fermented antler using Cordyceps militaris. J Ethnopharmacol, 133, 710-717

23. Lee IS, Lee SO, Kim HS (2002) Preparation and quality characteristics of yogurt added with Saururus chinensis (Lour.) bail. J Korean Soc Food Sci Nutr, 31, 411-416

24. Kang SK (2007) Changes in organic acid, mineral, color, curcumin and bitter substance of Curcuma Longa L. and Curcuma atomatica Salib according to picking time. Korean J Food Preserv, 14, 633-638

25. Jung SH (2003) Optimization of curcumin extraction from turmeric (Curcuma longa L.) using supercritical fluid and related physiological effects. Ph D Thesis, Chungnam National University, Korea

26. Shon MS, Kim GN (2014) Anti-oxidant and anti-obese activities of turmeric (Curcuma longa L.) extract in 3T3-L1 Cells. Kor J Aesthet Cosmetol, 12, 169-175

27. Nivea M, Sampietro A, Vattuone M (2000) Comparison of the free radical scavenging activity of propolis from several regions of Argentina. J Ethnopharmacol, 71, 109-114

28. Re R, Pellegrini N, Proteggente A, Pannala A, Yang M, Rice-Evans C (1999) Antioxidant activity applying an improved ABTS radical cation decolorization assay. Free Radic Biol Med, 26, 1231-1237

29. Green LM, Reade JL, Ware CF (1984) Rapid color metric assay for cell viability: Application to the quantitation of cytotoxic and growth inhibitory lympolines. J Immuno Methods, 70, 257-268

30. Choi JH (2010) Effect of Rosmarinus offcinalis L. on anti-inflammation and anti-gout. MS Thesis, Keimyung University, Korea, p 12
31. Wang SJ, Chen Y, He DD, He LY, Yang YM, Chen JZ, Wang XX (2007) Inhibition of vascular smooth muscle cell proliferation by serum from rats treated orally with gastrodia and uncaria decoction. A traditional Chinese formulation. J Ethnopharmacol, 114, 458-462

32. Lim JS, Lee SP (2014) Production of Set-type Yogurt Fortified with Peptides and 8 -aminobutyric acid by Mixed Fermentation Using Bacillus subtilis and Lactococcus lactis. Korean J Food Sci Technol, 46, 165-172

33. Kim DS (2009) Study on the condition of fermentation in lactic acid bacteria for the production of $\gamma$ -aminobutyric acid. MS Thesis, Hannam University, Korea, p 1-4

34. Lee HS, Chang MJ, Kim SH (2010) Effects of poly- 8 -glutamic acid on serum and brain concentrations of glutamate and GABA in diet-induced obese rats. Nutr Res Pract, 4, 23-29

35. Choi SN, Choi EH, Yoo SS (2013) Quality characteristics and antioxidative activities of majakgwa added with fermented turmeric powder. Korean J Food Cookery Sci, 29, 223-231

36. Kang MJ (2005) Antioxidative activity of Rhus verniciflua Stokes and effect of its extracts on quality of pork. PhD Thesis, Gyeongsang National University, Korea, p 19-20

37. Lee KA, Chung HY (2007) The biological activity of deer antler extract in vitro. J Korean Soc Food Sci Nutr, 20, 114-119

38. Lee KA, Chung HY (2004) Biological activities of a Korean traditional prescription, Nogyongdaebotang. J Korean Soc Food Sci Nutr, 33, 28-33

39. Kim NY (2010) Comparison of the anti-inflammatory effects of water fermented and ethanol fermented extracts from Rhei Radix et Rhizoma. $\mathrm{Ph} \mathrm{D}$ Thesis, Wonkwang University, Korea, p 9-10

40. Kawamata H, Ochiai H, Mantani N, Terasawa K (2000) Enhanced expression of inducible nitric oxide synthase by Juzen-taiho-to in LPS activated RAW 264.7 cells, a murine macrophage cell line. Am J Chin Med, 28, 217-226

41. Tak HM, Kang MJ, Kim KM, Kang DW, Han SK, Shin JH (2014) Anti-inflammatory activities of fermented black garlic. J Korean Soc Food Sci Nutr, 43, 1527-1534 